Article

\title{
The Role and Influence of Industry 4.0. in Airport Operations in the Context of COVID-19
}

\author{
Miroslav Drljača ${ }^{1, * \mathbb{D}}$, Igor Štimac ${ }^{2,3} \mathbb{D}$, Matija Bračić $^{3}$ and Saša Petar ${ }^{4}$ \\ 1 Integrated Management System and Consulting Department, Zagreb Airport Ltd., University North, \\ Croatia \& Croatian Quality Managers Society, Rudolfa Fizira 1, 10410 Velika Gorica, Croatia \\ 2 Airport Operations and Maintenance Supervision Department, Zagreb Airport Ltd., Rudolfa Fizira 1, \\ 10410 Velika Gorica, Croatia; istimac@zagreb-airport.hr \\ 3 Department of Air Transport, Faculty of Transport and Traffic Sciences, University of Zagreb, \\ 10000 Zagreb, Croatia; mbracic@fpz.unizg.hr \\ 4 Department of Sustainable Mobility and Logistic, University North, 48000 Koprivnica, Croatia; \\ sasa.petar@unin.hr \\ * Correspondence: mdrljaca@zagreb-airport.hr
}

Received: 4 December 2020; Accepted: 17 December 2020; Published: 18 December 2020

\begin{abstract}
Due to the COVID-19 pandemic, aviation at the global level is currently facing one of the biggest challenges in its sustainability. The entire philosophy related to airport operations and passenger processing changes due to the fast-spreading nature of this disease. The "new normal" in the aviation sector, primarily at the airport, will provide the passenger a different quality level of service in comparison to what we used to have until now. Following World Health Organization measures, especially those related to social distances, the future focus will be on the implementation of fully automated self-service passenger traffic flows that will change the airport passenger traffic flows' processing structure. This paper shows current technologies and processes and how this "new normal" will change philosophy related to Industry 4.0 at the airport passenger operations, functionality, and human resource (HR) planning and optimizations.
\end{abstract}

Keywords: airport operations; Industry 4.0; human resource; COVID-19; airport business

\section{Introduction}

Through history, air traffic shows, positive growth trend, with several crises such as global recession, terrorism, and epidemic crises (Severe acute respiratory syndrome (SARS), Middle East respiratory syndrome (MERS), Bird flu). However, all of those crises were short-term, and after a few months, air traffic was stabilized, but the situation with the COVID-19 virus is different.

On 31 December 2019, the World Health Organization (WHO) in China received a report from local health authorities on the occurrence of viral pneumonia in Wuhan's city. On 10 January 2020, the WHO issues a package of measures to combat the emerging disease, including health measures and travel tips. It was still unknown precisely how the disease was transmitted, therefore travellers restrictions are imposed on the affected areas (Wuhan city) [1]. Those recommendations include avoiding close contact with people who show signs of respiratory problems, frequently maintained personal hygiene (mostly handwashing), and avoided close contact with animals [2,3]. Although the situation was complicated, no restrictions were published for international traveling, as no infected cases were not recorded outside Wuhan. So, it can be concluded that at that time, air transport operated regularly.

On 13th January, the first case outside China (in Thailand) was recorded, and a few days later, other cases were successively reported in the United States, Europe, entire Africa and South America, so COVID-19 becomes a global problem [1]. To compare traffic data, it can be seen that this virus has 
such an influence on air traffic that passenger traffic decreased 99\% in some months in 2020 compared with the same months in the year 2019. Figure 1 shows the difference in the flight congestion over Europe on 31 March 2019 (pre-COVID-19) compared to 29 March 2020 (COVID-19).

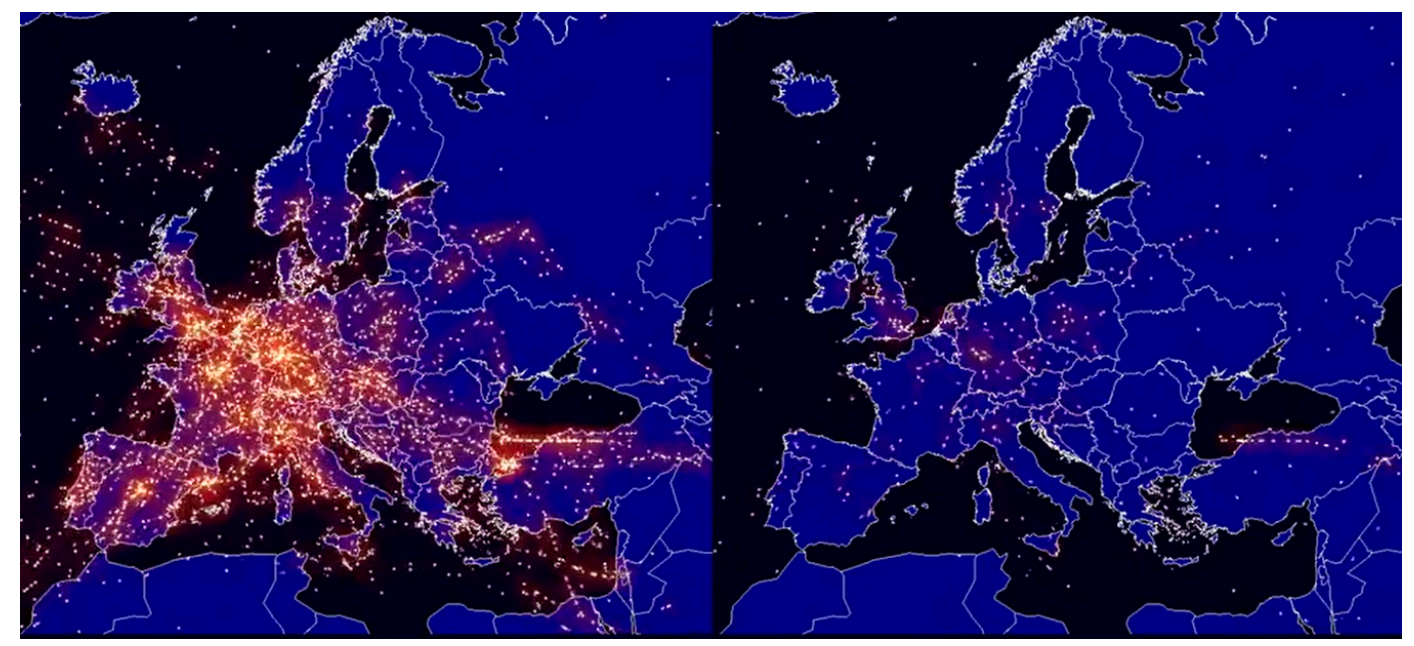

Figure 1. Flights in Europe on 31st March 2019 (pre-COVID-19) vs. 29th March 2020 (COVID-19) [4].

During the spread of COVID-19, the global economy starts to decrease, which has a huge implication on air transport as the demand for air transport services depends strongly on the Gross Domestic Product (GDP). A five-percent fall in GDP can be expected to result in a 5-10\% fall in demand and it is now clear that many countries nowadays register a fall of their GDP in a range from 5-10\%. However, COVID-19 has demonstrated the importance of other factors like health and safety, affecting demand even more dramatically. Most of the fall in air transport stems from the cross-border travel restrictions imposed by governments to limit the virus's transmission. [5].

The International Civil Aviation Organization (ICAO) announced a decrease of global passenger traffic of 69\% compared to 2019 (from January to August), with global losses to the industry between $\$ 350$ and $\$ 400$ billion. According to an ICAO statistic, an overall reduction of passengers (both international and domestic) ranging from 52\% to 59\% in 2020 compared to 2019 [6]. The International Air Transport Association (IATA) reports a $54.7 \%$ decline in revenue passenger kilometres (RPKs), both international and domestic, in 2020 compared to 2019 [7]. Two-thirds of the World's Passengers Jets are grounded due to the COVID-19 pandemic [8]. In Figure 2, it is shown that in history, no other crisis has affected air transport so significantly as the one related to COVID-19.

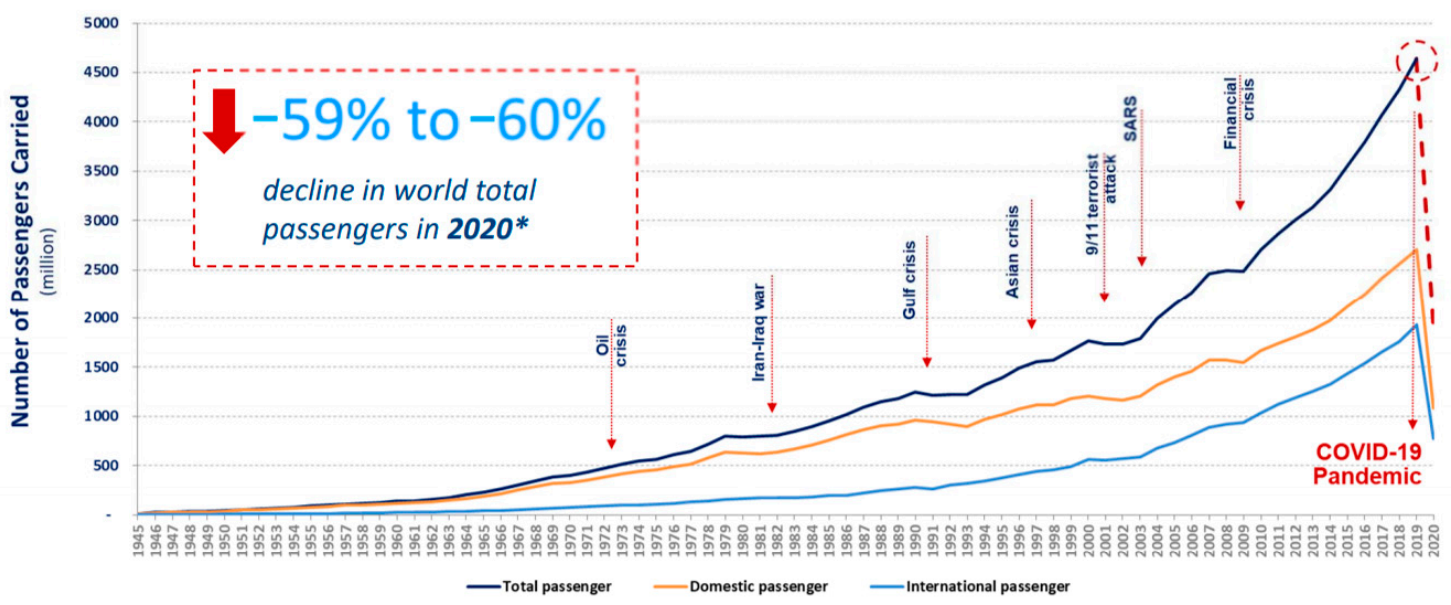

Figure 2. World passenger traffic evolution 1945-2020 [9]. 
According to a Bloomberg forecast [10], about 400,000 airline workers have been fired or they may lose their jobs due to the above-mentioned situation. Airport Council International (ACI) announced that on 1 March 2020, the decrease in passenger traffic at the European airports was 10\%. However, on the 5 April 2020, the decrease in passenger traffic at the European airports was $98 \%$ (it was the lockdown results). From 1 January 2020 till 19 July 2020, European airports recorded 886 million passengers less than in the same period last year [11]. The ACI estimated a loss of $57 \%$ or over $\$ 97$ billion airport revenues in 2020 compared to business as usual [12]. Eurocontrol announced that under its new "Current Status Scenario," the total number of flights expected in Europe in 2020 is anticipated to be $55 \%$ lower than in 2019 [13]. OAG aviation data provider reports that global airline seat capacity went below $56 \%$ [14].

Many countermeasures to prevent the spread of COVID-19 have been implemented by air companies and the International Air Transport Association (IATA). According to IATA, flights are categorized into three levels: (1) high-risk flights, (2) medium-risk flights, and (3) low-risk flights, and differentiated prevention and control measures are applied after a comprehensive evaluation of the outbreak at the place of origin of the flights, whether the aircraft is equipped with high efficiency particulate air filters, and other indicators such as load factors, flight time, and mission of the flights [15].

In the response to the COVID-19 crisis, it is important to take into consideration separated actions in three different time frames:

- Period three to six months after starting pandemic-How a company/business deals with the immediate impacts on and protection of the staff, travel and events, the company/business supply chains, operating locations, demand for the company/business products and services, cash flow, pricing, marketing, and brand reputation.

- The next twelve months-How the company revisits every aspect of the business and operating model-encompassing all of the above-if the virus and resulting economic impacts might continue to affect the company over the upcoming year.

- The next one to three years-How the company can change the shape of the business, location footprint, sourcing, and routes to market, product and service offerings, staffing models, and use of technology if the knock-on effects have a more dramatic impact on the company/business markets and the economy more widely [16].

For future airport business sustainability, the airport managers must avoid major mistakes such as focusing on the cash liquidation crisis instead of plan and turning the business into the "new normal." It will be crucial for the airport management to be more proactive and capable of implementing digital transformation to ensure the passengers safe and healthy air travel. [16].

Related to the research [17], one of the main responses to the COVID-19 crisis will be digitalisation. The following levels of airport digitalization mirror the objectives regarding operational efficiency and passenger experience enhancement:

- Airport operations-The efficiency of overall airport operations aims to optimize resources and improve processes related to maintenance, handling operations, security services, thus eliminating delays or other operational risks.

- Passenger journey-Targets to improve passenger perception and experience by handling congestion, ensuring a continuous flow, thus minimizing queues and maximizing a passenger's time spent in retail areas.

- Ancillary revenues-Non-aviation revenues can be increased by amending the retail area attractiveness, providing commercial information through mobile apps or digital walls, and using digital capabilities to perform online orders [17].

Following all previously described, it is clear that aviation is facing a new challenge. Aviation how it is currently known will not be the same in the future. New technology will be implemented at airports to decrease personal contact, so automated passenger flows will be recommended, such as 
e.g., Aruba Passenger Flow. Regarding the planning of passenger terminals interiors and passenger traffic flows, it can be seen that in the future, a new checkpoint (health inspection) will be added to the current traffic flow.

This additional checkpoint will, for sure, influence passenger dwell time and overall processing time. In line with new technology, employees will face new requirements, especially on human resource (HR) planning and organization. On the one hand, they will need to keep social distancing from the passengers, and on the other hand, they will need to help passengers at self-service checkpoints how to use new technology.

This paper represents how Industry 4.0, and in this regard HR management, will influence aviation normalization, focusing on airport business, and it will develop in the future.

\section{Materials and Methods}

Several scientific methods were used in the research as follows. The descriptive method is applicable in all parts of the paper, but it is mainly present in the background to describe Industry 4.0. Furthermore, this method is also present where the paper describes the structure, phasing, and functionality of the COVID-19 context. The system theory method has been applied in Smart Airport structuring and airport operations research since it is treated as a management system with its subsystems or structural elements. One of the structural elements is business processes, i.e., airport operations. The comparison method was applied in the research where innovations within Industry 4.0 implemented in airport operations in response to limitations in the handling process in the context of the COVID-19 pandemic were compared to the situation before. The method of analysis and synthesis were used to research limitations in certain activities in the processes due to epidemiological measures to conclude the effects of these limitations on airport operations. The method of induction and deduction was applied in the research for impact evaluation of certain process constraints on the overall airport operations at the global level, as well as the pandemic impact on individual airports and their adaptation through the implementation of innovation within Industry 4.0 and providing competent HR to work in the context of COVID-19.

The basic hypothesis of this paper is that Industry 4.0, and in this regard HR management, in order to develop the necessary competencies, will influence aviation normalization, focusing on airport business in the context of COVID-19 and it will develop in the future.

\section{Background}

The first industrial revolution (1.0) was started in the 18th century by the energy of water vapor, which enabled a higher degree of mechanization. In the 19th century, electricity replaced steam energy, and the construction of the first mechanized slaughterhouse in Cincinnati in 1870 was considered the beginning of the second industrial revolution (2.0). The third industrial revolution (3.0) was marked by the use of electronic and information-communication systems, and based on them, the complete application of automation in production processes. The invention of the PLC (Programmable Logic Controller) in 1969 begins the third industrial revolution [18]. Industry 3.0 was the result of massive development in computers and information and communication technology [19].

Industry 4.0 is one of the most important concepts in developing the global industry and the world economy. Industry 4.0 is a logical continuation of the previous three industrial revolutions and refers to the rapid digital transformation of manufacturing industries. Germany initiated Industry 4.0 in 2011, and it represents an incentive for industry development through automation production by using all modern production means known as Cyber-Physical System (CPS). These systems integrate computing techniques, data transmission and processing, and modern mechanical systems [20].

Industry 4.0 encompasses the development and integration of innovative information and communication technologies in the industry. The main goal is to encourage intelligent networking of products and processes along the entire supply chain (SC), allowing for more efficient use of 
organizational processes to create goods and services to enhance customer benefit by offering them new products and services [21].

Industry 4.0 enables the manufacturing sector to become digitalized with built-in sensing devices virtually in all manufacturing components, products, and equipment. The analysis of related data within a ubiquitous system with the fusion of digital data and physical objects can transform every industrial sector in the world to evolve much faster and with more significant impact than any of the three previous industrial revolutions [22]. This is achieved through simplified information exchange and the integrated control of manufacturing products and machines acting simultaneously and smartly in interoperability [23]. The improvement in technologies brings significant effects on industries, economies, and governments' development plans [24].

Industry 4.0 has brought changes to many professions. People are obligated to learn new skills and to use hi-tech gadgets to be able to perform everyday tasks [25]. Industry 4.0 is presented as an overall change by the digitalization and automation of every company and the manufacturing process. Big international companies that use continuous improvement concepts and have high standards for research and development will accept the concept of Industry 4.0 and make themselves even more competitive in the market [26]. Industry 4.0 enables the full use of emerging technologies and the rapid development of machines and tools to cope with global challenges to improve industry levels. The main concept of Industry 4.0 is to utilize advanced information technology to deploy the Internet of Things (IoT) services. Production can run faster and smoothly with minimum downtime by integrating engineering knowledge. Therefore, the product built will be of better quality; production systems are more efficient, easier to maintain, and achieve cost savings [27]. Therefore, Industry 4.0 is necessary to maintain competitiveness in any industry. To create a more dynamic production flow, the value of chain optimization has to be autonomously controlled [22]. Industry 4.0 describes a future industrial production scenario characterized by new levels of controlling, organizing, and transforming the entire value chain with the life cycle of products, resulting in higher productivity and flexibility through three types of effective integration: horizontal, vertical, and end-to-end engineering integration. Hence, these can predict product performance degradation and autonomously manage and optimize product service needs and consumption of resources, leading to optimization and cost reduction [25].

The fourth industrial revolution encompasses the entire supply chain (SC) of products from raw materials to production, delivery, support, maintenance, and waste management. It is based on recording and intelligent real-time management of all available data during the life cycle of products and production systems [28].

As with any significant change, there are challenges inherent in adopting Industry 4.0 models such as data security issues, reliability, the stability of automated systems, the integrity of manufacturing processes, or lack of experience and workforce to create and implement these systems. The benefits of Industry 4.0 are numerous: workers' health and safety could be improved,

- Industrial processes can be more easily controlled when there is real-time data at all production processes,

- Computer control, optimization, and automation can improve productivity and produce better quality and personalized products [29].

The transformation is based on intelligent networking of machines (and other devices) using advanced information and communication technologies to enable autonomous communication between devices, analyse and collect massive amounts of data, autonomous decision making, real-time monitoring of assets and processes, creating added values and vertical and horizontal integration as dominant concepts. Vertical integration is an approach that includes networked production systems that approach changes in the production process through alternative strategies. Horizontal integration represents a standard SC as an optimized flow of raw materials and information from different global value chain suppliers to end-users. The primary purpose is to deliver the product according to customer requirements. The basis is the integration of information technology with operational activities, leading to a more vital production organization. 


\section{Results}

All of the above also applies to airport business and operations. In the context of airport operations, Industry 4.0 can be defined as integrating modern Information Communication Technology (ICT) with conventional operational processes of aircraft handling, passengers and baggage handling, and cargo handling, which allows the provision of services in special circumstances such as COVID-19. It is about intelligent networking of equipment and devices using ICT to enable autonomous communication between units of equipment and devices, analysing and collecting massive amounts of data, autonomous decision making, monitoring airport assets and operational processes in real-time, and creating added value for the passenger and other users of airport services. Industry 4.0 applied to airport operating processes are geared towards finding an answer to how this integration can provide an individual benefit to the passenger, which he/she is willing to use and pay for, and in the context of COVID-19.

\subsection{Smart Airport Assumptions in the Context of COVID-19}

Following the above mentioned information, there is possibility for applying the Industry 4.0 on Smart Airport Concept. Smart Airport is a complex structure made up of smart structural elements, i.e., assumptions as following:

- Smart Airport Mobility means sustainable mobility of passengers, employees, and other airport visitors. This refers to the fastest route and the use of different means of transport such as subways, railways, bicycles, and electric cars. The capacity of access roads and parking lots should be sufficient.

- Smart Airport Logistics implies the appropriate dynamics of procurement of goods and services required for airport operations, traffic routes that connect the airport with cities in the vicinity and the wider geographical area. All the logistics elements that makeup Smart Airport Logistics should also be based on smart technologies.

- Smart Airport Infrastructure includes a passenger terminal, runway, apron, and other operating areas managed sustainably, using ICT. Apart from the passenger infrastructure, the same applies to the cargo infrastructure (warehouse, access roads, parking lot, exit to the parking lot, etc.).

- Smart Airport Services include automated business processes of aircraft, passengers, cargo, and mail handling in all phases while minimizing the activities performed by the airport's operational staff.

- Smart Airport Equipment reduces physical human work, speeds up airport operations, and minimizes the environment's negative impact.

- Smart Airport Grids are necessary for Smart Airport Services, Smart Airport Infrastructure, Smart Airport Logistics, Smart Airport Mobility, and the functioning of Smart Airport Equipment.

The creation of Smart Airport aims to minimize direct physical contact of passengers and other users of airport services with airport staff, speed up business processes, optimize costs, increase safety, reduce the risk of infection, and ensure a high level of service quality that meets the requirements of passengers and other airport users. Smart Airport assumptions in the context of COVID-19 can be seen in Figure 3.

All the above listed structural elements need to function in order to be able to understand Smart Airport Concept. Without any of the listed structural elements, one would not be able to talk about Smart Airport. It is necessary to observe Smart Airport as an emerging phenomenon, at least for the following reasons:

1. technologies are constantly evolving.

2. the requirements of airport service users are constantly changing.

3. airport infrastructure requires a constant investment that takes place in cycles

It should be emphasized that the smart airport process must continually evolve based on the situation in the global market. The situation with the COVID-19 pandemic will additionally accelerate 
transition to a Smart Airport. On the other hand, due to numerous restrictions, the airport's financial revenues are significantly disrupted or reduced.

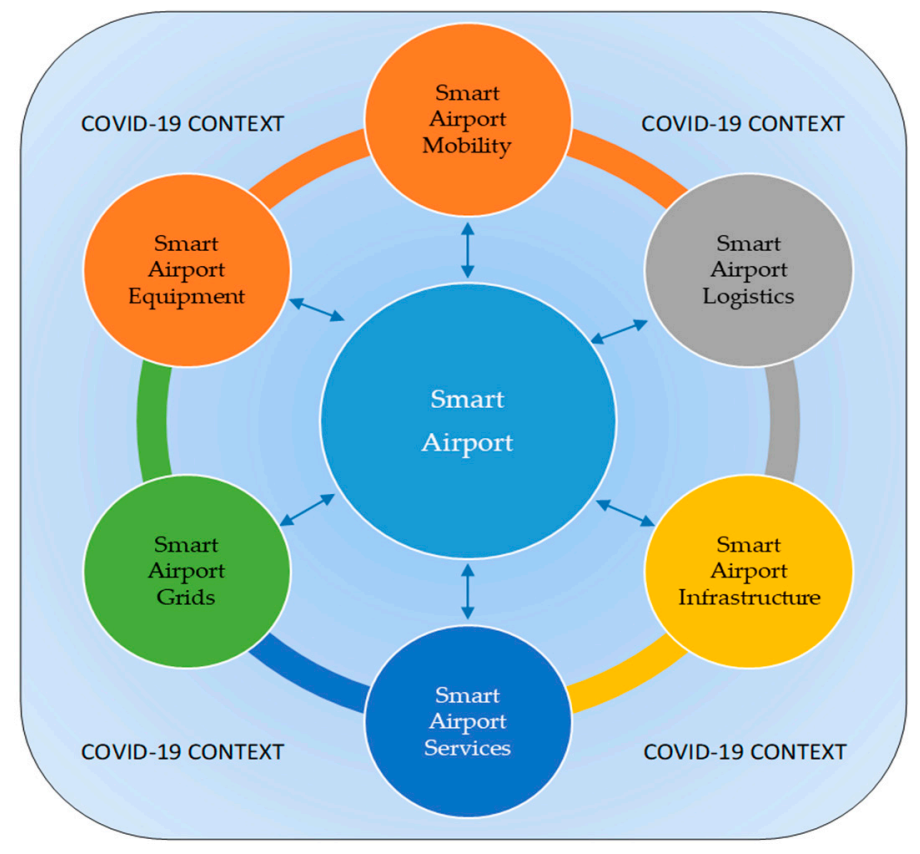

Figure 3. Smart Airport assumptions in the context of COVID-19.

After evaluating the situation with the COVID-19 pandemic, it can be emphasized that Industry 4.0, with all its technology, will have a strong influence on passenger behaviour and passenger terminal subsystems through traffic. Pre-COVID-19 activities were mostly based on a direct contact between a passenger and the airport staff on each passenger terminal subsystem, such as check-in, security, immigration, emigrations, and customs. After implementing WHO recommendations (social distance, disinfection, passenger number in commercial areas), airport space and capacity have become a huge problem for many airports. As a response to those challenges and to ensure a stable and sustainable business, airports will need to implement the whole new technology used under Industry 4.0, such as contactless IT technology, biometrics, and the digitalization of documentation. The implementation of Industry 4.0 technology will reduce time and ensure convenient and trustful travel for air transport passengers. Table 1 shows the pre-COVID-19 and the post-COVID-19 traffic flows in passenger terminals, with a special focus on the implementation of Industry 4.0.

Table 1. Implementation of the Industry 4.0 in airport terminal subsystems over traditional passenger flow.

\begin{tabular}{ccccc}
\hline \multirow{2}{*}{$\begin{array}{c}\text { Terminal } \\
\text { Subsystem }\end{array}$} & \multicolumn{2}{c}{ Pre-COVID-19 Passenger Flow } & \multicolumn{2}{c}{$\begin{array}{c}\text { COVID-19 Passenger Flow and Future } \\
\text { Vision with Industry 4.0 }\end{array}$} \\
\cline { 2 - 5 } & Technology & $\begin{array}{c}\text { Social } \\
\text { Contact }\end{array}$ & Technology & $\begin{array}{c}\text { Social } \\
\text { Contact }\end{array}$ \\
\hline \multirow{2}{*}{$\begin{array}{c}\text { Check in } \\
\text { (CKI) }\end{array}$} & $\begin{array}{c}\text { Most of the passengers use } \\
\text { conventional check-in desk } \\
\text { service (direct contact between } \\
\text { passenger and airport staff) }\end{array}$ & Yes & $\begin{array}{c}\text { Using conventional Check-In } \\
\text { service will be decreased as focus } \\
\text { will be on contactless technology. } \\
\text { Using of CKI desk service will be } \\
\text { additionally paid. }\end{array}$ & Yes/ \\
& No & & \\
\hline
\end{tabular}


Table 1. Cont.

\begin{tabular}{|c|c|c|c|c|}
\hline \multirow{2}{*}{$\begin{array}{l}\text { Terminal } \\
\text { Subsystem }\end{array}$} & \multicolumn{2}{|l|}{ Pre-COVID-19 Passenger Flow } & \multicolumn{2}{|c|}{$\begin{array}{l}\text { COVID-19 Passenger Flow and Future } \\
\text { Vision with Industry } 4.0\end{array}$} \\
\hline & Technology & $\begin{array}{l}\text { Social } \\
\text { Contact }\end{array}$ & Technology & $\begin{array}{l}\text { Social } \\
\text { Contact }\end{array}$ \\
\hline & $\begin{array}{l}\text { Self-Service Kiosk-the average } \\
\text { number of passengers (mostly } \\
\text { business passengers) use } \\
\text { Common use self-service (CUSS) } \\
\text { due to a lack of IT knowledge }\end{array}$ & No & $\begin{array}{l}\text { Self- Service kiosks will become } \\
\text { the standard technology for } \\
\text { passenger check-in. The } \\
\text { additional value will be that } \\
\text { during CKI, passenger data from } \\
\text { the passport will be correlated } \\
\text { with the biometrics (face } \\
\text { recognition) used as an identity } \\
\text { base through the entire traffic } \\
\text { flow process. }\end{array}$ & No \\
\hline & $\begin{array}{l}\text { Bag Drop Desk-if there is no } \\
\text { automated bag drop, passengers } \\
\text { after CUSS of web check-in are } \\
\text { going to the Drop-Off counter } \\
\text { (direct contact between passenger } \\
\text { and airport staff) }\end{array}$ & Yes & $\begin{array}{l}\text { Bag Drop Desk will be fully } \\
\text { automated without any contact } \\
\text { with the airport staff. }\end{array}$ & No \\
\hline & $\begin{array}{l}\text { Internet CKI_low rate of using } \\
\text { Internet/Web Check-In }\end{array}$ & No & $\begin{array}{c}\text { Internet CKI will have a high } \\
\text { usage rate because most } \\
\text { passengers will use their IT } \\
\text { equipment for CKI. }\end{array}$ & No \\
\hline $\begin{array}{l}\text { Boarding Pass } \\
\text { Control }\end{array}$ & $\begin{array}{l}\text { Most of the airports still airport } \\
\text { stuff for checking boarding pass } \\
\text { (direct contact between passenger } \\
\text { and airport staff) }\end{array}$ & Yes & $\begin{array}{l}\text { All the airports will use } \\
\text { automated boarding pass control } \\
\text { equipment where employees will } \\
\text { be monitoring the entire process } \\
\text { from a distance (separate office). }\end{array}$ & No \\
\hline $\begin{array}{l}\text { Security } \\
\text { Control }\end{array}$ & $\begin{array}{l}\text { Most of the airports use } \\
\text { conventional security equipment } \\
\text { where four persons need to be in } \\
\text { place for one security unit (direct } \\
\text { contact between passenger and } \\
\text { airport staff) }\end{array}$ & Yes & $\begin{array}{l}\text { Airport Security will be using } \\
\text { highly sophisticated equipment, } \\
\text { including scanning cabin (a } \\
\text { touchless, digital alternative to } \\
\text { physical security). The officers } \\
\text { will monitor the entire process } \\
\text { from a distance (separate office) } \\
\text { and will react only if the alarm } \\
\text { is on. }\end{array}$ & No \\
\hline $\begin{array}{l}\text { Emigration/ } \\
\text { Immigration } \\
\text { Control }\end{array}$ & $\begin{array}{l}\text { Emigration and Immigration are } \\
\text { provided by police, and most of } \\
\text { the airport use a conventional } \\
\text { approach with emigration } \\
\text { counters (direct contact between } \\
\text { passenger and police officer) }\end{array}$ & Yes & $\begin{array}{l}\text { The airport will implement } \\
\text { technology which will provide } \\
\text { biometrics and date from the } \\
\text { mobile (passenger face will } \\
\text { become boarding pass). }\end{array}$ & No \\
\hline Boarding & $\begin{array}{l}\text { Most of the airport is using a } \\
\text { conventional boarding process } \\
\text { using gate counters (direct contact } \\
\text { between passenger and } \\
\text { airport staff) }\end{array}$ & $\begin{array}{l}\text { Yes/ } \\
\text { No }\end{array}$ & $\begin{array}{l}\text { Automated gate readers and face } \\
\text { recognition will create contactless } \\
\text { boarding checks while airport } \\
\text { employees will monitor the entire } \\
\text { process from a distance office. }\end{array}$ & No \\
\hline
\end{tabular}

\subsection{Smart Airport Human Resource Management}

Various terms of almost identical meaning appear in national and world literature related to people as thinking beings, such as personnel, staff, worker, employee, official, recruits, clerk, workforce, human resources, human potential, and human or intellectual capital [30].

Despite the similarity of these terms and the fact that some of them are often used as synonyms, their meaning is different. Besides some similarities with other terms, the term "human potential" also has some particularities. This expression replaces the previous term cadre or personnel department in order to emphasize the importance of people and their development as a significant resource and points out a new approach to the human capital in capital relationships. A human with his knowledge and ability, acting in production processes and other activities is a resource and a potential. However, 
human potentials are abilities of a human being who carries them inside as inborn properties that other resources lack [30].

Human resources are a group of individuals making the workforce of an organization, business sector, or economy. From the organization aspect, employees are considered part of their assets whose value increases through development [31].

A characteristic for the dominating concept of neoliberal capitalism is the so-called "hard management." Those managers try to maximize productivity and profit and see a worker as a resource. On the opposite side, "soft management" of human resources is open to the development of employees, is not inclined to firing people (except in extreme cases), and also considers the interests of employees [32].

In the work and education context, competencies seem to be something that can no longer be ignored. Educational programs are focused on their development, while selection procedures aim to select the "most competent" individuals for a job. As is usually the case with commonly used terms, competencies have gained their life and become a kind of entity. However, their popularity also requires a scientific approach. Prior to their use in practice, they need to be adequately defined, clearly operationalized, and develop proper and reliable measures for their evaluation [33].

A competent person is considered to be a person qualified to perform a job. Competences refer to an individual's ability to, following the expectations from him/her as an expert qualified for a field, adequately and efficiently perform certain tasks [34].

In accordance with the previously stated, competent employees are needed to conduct airport operations. Competence is a complex concept and does not represent just a formal education (high school or college education) of an individual. The competence consists of four elements (as shown in Figure 4.): (1) basic formal education, (2) specialist education, (3) practical experience, and (4) psychosocial characteristics.

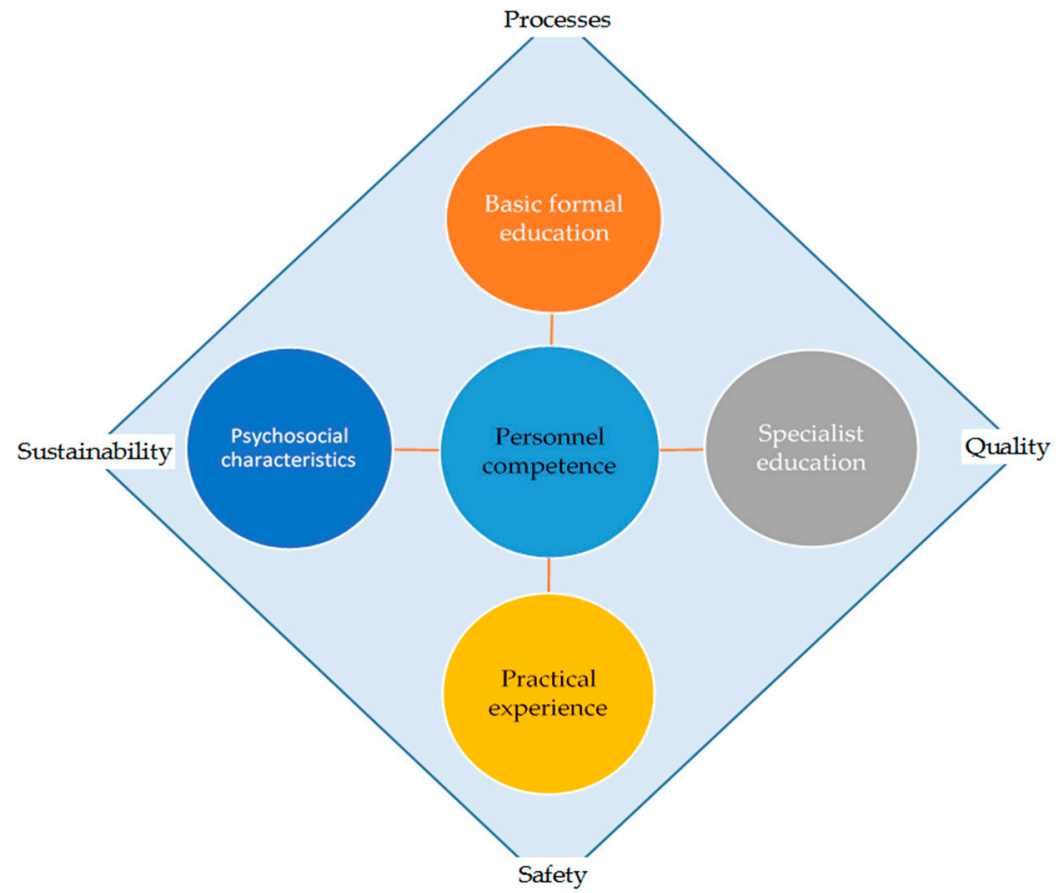

Figure 4. Smart Airport assumptions in the context of COVID-19.

Airport staff competence implies a critical mass of knowledge about the phenomena shown in Figure 4 that requires: (1) understanding the process approach, handling process, and employee position and role in the process; (2) the meaning of focusing on the passenger and other service 
users and the application of quality management principles; (3) the importance of safety for airport operations, and (4) the need for sustainable business in the long run.

Basic formal education (BFE) - in the context of the airport HR, it would be desirable, but not necessary, that airport employees have air transport education, regardless of the job specification. Depending on the job specification, in this category, aviation, high school, or traffic and transport faculty should be appropriate. However, this is often not the case, but workers who have a high school or college degree from a social or technical field are employed. Therefore, it can be concluded that BFE is not an elimination factor in the recruitment process, mainly because the employer will organize specialized aviation education closely related to their job description.

Specialist education (SE) - regardless of BFE employee background, it is necessary to conduct an SE in the first few months, i.e., working under a mentor's supervision. It is a practical work where a specialist is still not independent and where the mentor has all responsibility. After a certain period, depending on the job requirements, the responsible person will evaluate practical work. SE is performed throughout the entire working period of the employee and it could be achieved through education in certain aviation specialist programs. Almost all airport jobs require a specific license (ramp handling, aircraft weight and balance, DGR). To obtain these licenses, each employee working on those jobs must complete a specific SE program, have Practical Experience (PE), and pass an exam (mostly done by the Civil Aviation Agency). Licenses are not perpetual but need to be renewed over time (2-3 years). Based on the above allegations, it can be concluded that SE is a concept of lifelong learning based on technology and Industry 4.0 development and the emergence of new circumstances such as COVID-19.

Practical experience (PE)—over time, the employee acquires certain experience and skills required to perform specific operational processes in a quality, safe, and sustainable manner. The combination of PE, BFE, and SE creates the employee's preconditions to become competent to perform tasks in the airport's operational processes. However, even that is not enough. What an individual can do directly depends on the level of his professional functioning. Competencies are context-dependent because the employee over a period of time gains more experience and becomes competent to deal with increasingly complex tasks [35].

Psychosocial characteristics (PC) - the psychosocial climate is the overall perception of interpersonal relationships in a group or organization. One of the airport management's main goals is to create an organizational climate that will encourage employees to be constructive and productive. The workers' behaviour and their perception during the different airport's situation significantly determines and creates a psychosocial climate. In the building team process, it is necessary to take into consideration the psychosocial characteristics of each individual. An employee can have different psychosocial characteristics: some of them can be strong individually, others can have good leadership characteristics and abilities, the third will not respond well to a critic, etc. Therefore, the airport management should always keep in mind the importance of social modelling and that they are responsible for modelling behaviour, which means that they need to show which behaviours and attitudes are socially desirable and acceptable. In this way, among other things, conflict is prevented, and team synergy is ensured.

Personnel competence (PCO) is not a condition; it is a process. Building competent individuals, teams, and processes are complex. It requires time and financial investment in employees, which have the character of investment and are a precondition for transforming human potential into human capital.

HR management is categorized as a support process or a logistics business process or a so-called resource business process. The reason for this is that human resource potential, i.e., people, is considered a resource that support, meaning it represents a logistic support to the core business processes and through them, that is to say indirectly, creates and transfers added value to the end user by means of products or services having their materialization in the market [35]. 
HR management process as a management function may be decomposed, i.e., divided into structural elements or components, called process steps. Figure 5 shows decomposition, the structure of this process from which it may be concluded that this business process is modelled from the following process steps: (1) planning, (2) employment, (3) monitoring, (4) education and professional training, (5) career management, and (6) final activities. Process step (5) career management is a process step that makes the difference between organizations from the viewpoint of HR management quality. It is difficult for organizations that have not developed and documented this process step to prove (document) the management of this business process [36].

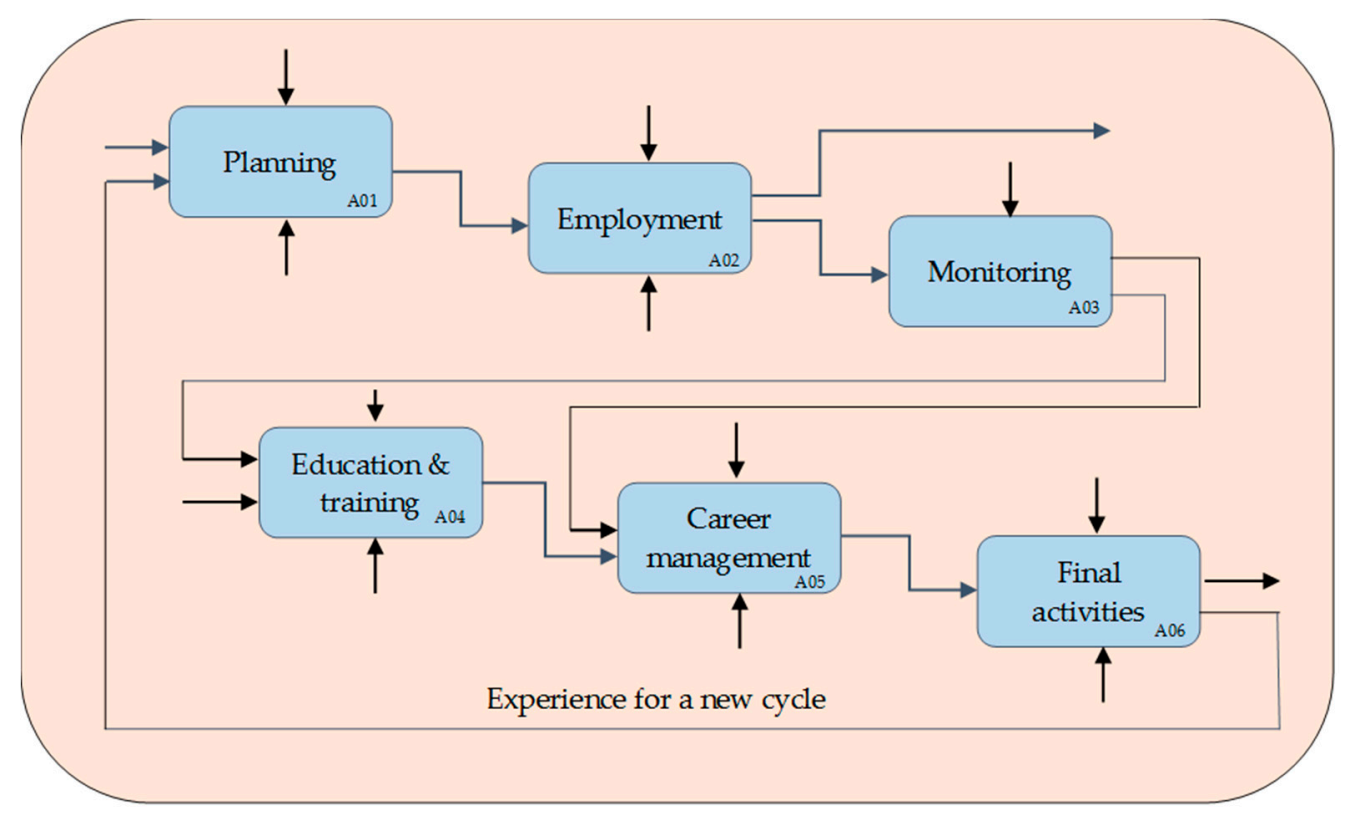

Figure 5. Decomposition diagram of the HR management business process.

PCO implies the presence of BFE, SE, PE, and PC. If any of these structural elements of competence is missing, one cannot speak of a PCO.

$$
\begin{aligned}
& \mathrm{BFE}+\mathrm{SE}+\mathrm{PE}+\mathrm{PC}=\mathrm{PCO} \\
& \mathrm{BFE}-\mathrm{SE}+\mathrm{PE}+\mathrm{PC} \neq \mathrm{PCO} \\
& \mathrm{BFE}+\mathrm{SE}-\mathrm{PE}+\mathrm{PC} \neq \mathrm{PCO} \\
& \mathrm{BFE}+\mathrm{SE}+\mathrm{PE}-\mathrm{PC} \neq \mathrm{PCO} \\
& \mathrm{SE}+\mathrm{PE}+\mathrm{PC}-\mathrm{BFE} \neq \mathrm{PCO}
\end{aligned}
$$

PCO and competent airport staff are crucial for managing innovation in the application of Industry 4.0 in airport operational processes. Only competent airport management and other airport employees can create a Smart Airport that can meet all the requirements of its users (passengers, airlines, consumers, guests, tenants, and others) both in normal conditions and in adverse conditions, such as COVID-19 context. Figure 6 shows the symbiosis and interdependence of these three phenomena: (1) PCO, (2) Smart Airport based on innovations within Industry 4.0, and (3) complex context like COVID-19 context. 


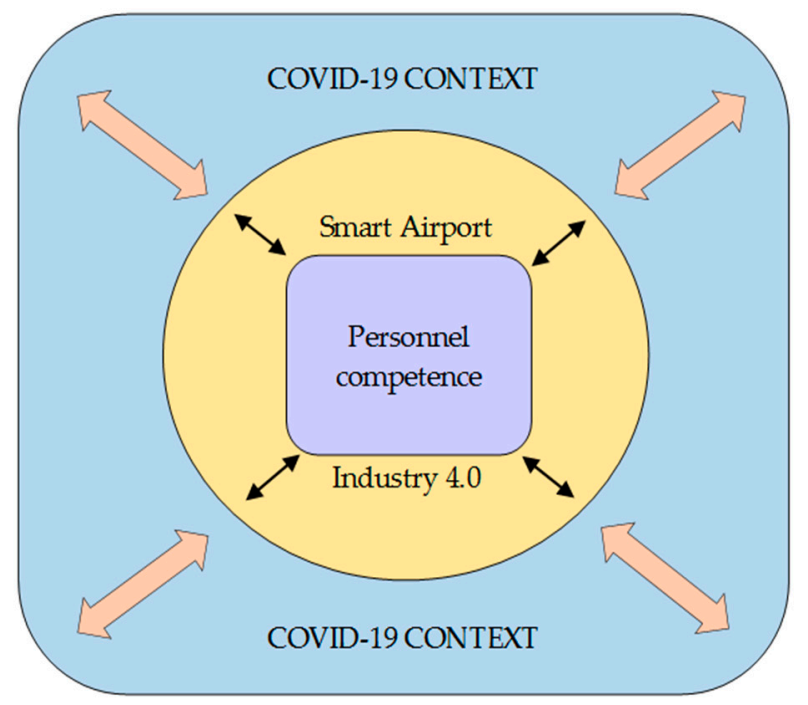

Figure 6. Relationship between Personnel competence, Industry 4.0 and context.

To operate in an increasingly complex context with many constraints and new rules (which frequently change) to manage business processes based on innovation within Industry 4.0, it is necessary to understand the process approach, know the participants in the process, understand the users' requirements, and perceive and understand the context. As the context changes over time, as business processes change as well as innovations within Industry 4.0, as customer requirements are becoming more demanding, airport staff must continuously work on their PCO and maintain it at an adequate level. The concept of lifelong learning is imposed here as an appropriate solution.

This approach requires a new paradigm, and the main thing is the establishment of an adequate new business model and long-term sustainability of airport operations, even in terms of future adverse conditions. The new business model (Figure 7) starts from the fact that the existing one is not functional and is inapplicable in the new context of the pandemic.

However, it also starts from the fact that the users of airport operations services have the right to request travel services, etc. Airports seek, as before the pandemic, to enable their operational processes to a level that allows these requirements to be met. This is possible by designing the Smart Airport Concept as shown in Figures 3 and 4.

The peculiarity of this model is that it has a clearly defined requirement, which is contactless procedures. Furthermore, this goal must be achieved in the shortest possible time to allow air traffic sustainability due to the current situation withCOVID-19. The contribution of this model is that it applies to other contact-restricted situations besides COVID-19. In addition, contactless procedures at airports will be implemented long before they would have been if the pandemic had not occurred. This will greatly facilitate and speed up the airports' operational processes, increase the quality of service, and reduce operating costs. Therefore, designing a new airport business model is an unstoppable process that, despite current financial and other difficulties, ensures the long-term sustainability of airport operations globally. 


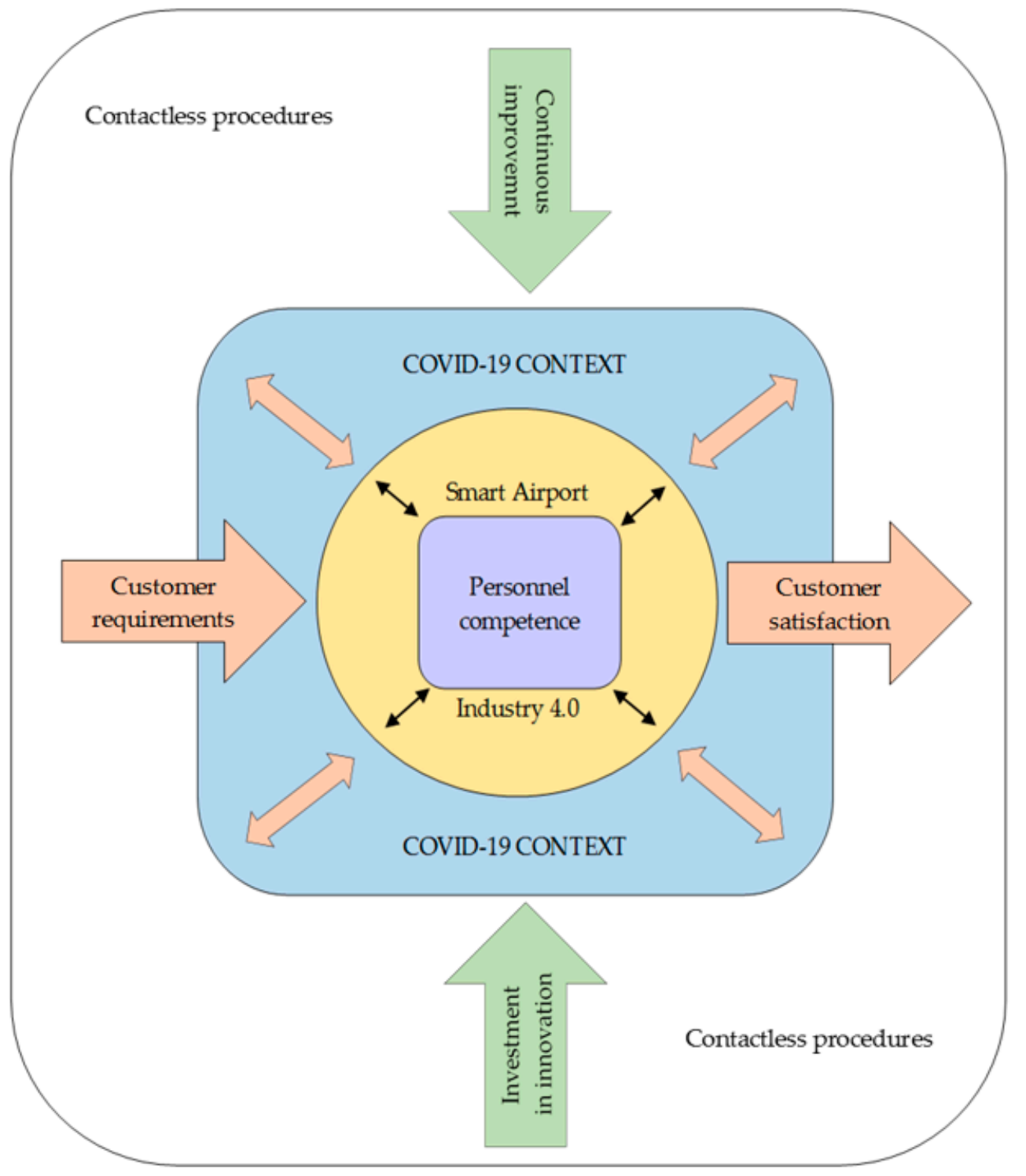

Figure 7. A new airport business model in the context of COVID-19.

\section{Discussion}

Research into each phenomenon requires its consideration in context. In the case of this article, the subject of the research, Industry 4.0 at the airport passenger operations, functionality, and HR planning and optimizations is being researched in the context of COVID-19. This context is characteristic on the global level and has a major impact on the air transport industry, including airport operations. However, on the 5 April 2020, the decrease in passenger traffic at the European airports was $98 \%$ (it was the lockdown results). During November 2020 and in early December 2020, a new partial lockdown has been applied in certain parts of the world, especially Europe. In order to combat the pandemic, at the global level, airport operations and air transport made several restrictions: passengers' movement, entry/exit restriction applied by individual country, number of passengers on board, the distance between passengers and passengers and airport staff during activities in the passenger handling process, etc. All this significantly affects the motivation to travel, causes a large reduction in the number of passengers in air transport, and thus at airports. As a result, airports are not generating revenue, laying off staff, delaying infrastructure investments, borrowing credit, which will have an impact on business even a few years after the end of the pandemic. Numerous airlines went bankrupt, and others manage to sustain the business (with state financial assistance) but with 
significant financial losses, excess capacity, and cancellations. This context and the constraints have influenced airport management and air transport organizations in general. The implementation of various adaptations aim to enable air travel even in these difficult circumstances. In order to ensure the airport business process despite various limitations, it was necessary to devise adjustments aimed at respecting epidemiological measures on the one hand and at the same time conducting airport operations in the new circumstances, on the other. The application of solutions within Industry 4.0 is one of the most important concepts in developing the global industry and the world economy, as well as the airport business. This primarily refers to new technologies being implemented in airport operations. The improvement in technologies is bringing significant effects on industries, economies, and governments' development plans. The application of Industry 4.0 to airport operations can be based on Smart Airport Concept. Technological solutions ensure the implementation of the passengers and baggage handling and aircraft and cargo handling in compliance with all the above epidemiological measures. These new technological solutions encompass all airport operations. Considered from an aspect of passengers and baggage handling process, they are reflected primarily in the following technological solutions within Industry 4.0 at airports: [37]

- Check-in: allowing passengers to receive their boarding pass via self-service channels (web, kiosk, mobile phone, or automated), avoiding long lines at check-in desks.

- Biometrics: as airports and airlines invest in digitization of all passenger touchpoints and implement self-service systems (check-in, bag drop, security, boarding), biometrics will become the preferred technology for identity management. Furthermore, biometric data, when linked with boarding pass data, is of immense value to airport operators. These datasets will allow a transformation of airport business models, as airports learn more about passengers and can develop personalized products and services.

- Bags ready-to-go: enabling passengers to deliver their bags tagged and ready for acceptance. This self-tagging could be done at kiosks, through Home Printed Bag Tags or Electronic Bag Tags. Baggage would then be accepted by an airline representative or a self-service bag drop.

- Document scanning: allowing passengers to scan their travel documents at kiosks for data verification and compliance with destination and transit requirements.

- Flight rebooking: allowing passengers to get proactively rebooked and obtain their new boarding pass via a self-service channel such as kiosks in case of delays or cancellations, thus avoiding long lines.

- Self-boarding: allowing passengers to self-scan their boarding token to gain entry to the aircraft, potentially using automated boarding gates similar to a train or metro station.

- Bag recovery: enabling passengers to report a missing bag via a self-service channel instead of waiting in line at a baggage claim service counter.

- Robots: there was lots of talk about customer-facing robots that can provide on-the-spot assistance to passengers but it is perhaps in operational roles that robotics will have the most telling impact. Many airports are already utilizing robots somehow, such as Tokyo International Airport. Many others are planning to follow through.

- Collaborative decision-making: airport collaborative decision-making aims at improving the overall efficiency of airport operations by optimizing the use of resources and improving the predictability of events. It focuses especially on aircraft turn-round and pre-departure sequencing processes. Increased predictability can be of significant benefit for all major airport and network operations; it raises both productivity and cost-efficiency. These benefits will apply to the Airport Operator, Airline, Air Traffic Control, Ground Handler, Passengers, and the entire aviation network.

- One ID by IATA: one ID seeks to introduce a collaborative identity management solution that spans all process steps and stakeholders in the end-to-end journey from booking to arrival at destination and back, putting the passenger in the centre. The concept relies on early validation of the passengers' identity, and controlled access to this information by the various public and 
private stakeholders on an authorized-to-know basis, so that the passenger can be recognized and attended to in the most efficient way in subsequent process steps. One ID introduces an opportunity for the passenger to further streamline their journey with a document-free process based on identity management and biometric recognition. Passengers will be able to identify themselves at each airport touchpoint through a simple biometric recognition. The objective is to achieve a truly interoperable system coordination between airports, airlines, and governments.

New technologies also require new competencies. Airport staff need to continuously acquire new knowledge and skills in order to be able to manage new technologies within airport operations. In addition to BFE, this includes SE as well as PE and PC. All this makes the PCO, without which there is no proper application of new technologies in airport operations. To achieve this aim, it is necessary to have a well-modelled and managed HR management process. In order to respond to the challenges of the COVID-19 context globally, it is necessary to strike a balance between different phenomena. On the one hand are pandemics and restrictions aimed at preventing the spread of infection, and on the other hand, innovation within airport operations, based on the Industry 4.0 concept and HR management. This structure produces a synergistic effect and provides the necessary infrastructure and superstructure for the conduct of airport operations in the context of COVID-19 on a global level.

In this way, it was also confirmed the hypothesis of this research that Industry 4.0, and in this regard HR management, in order to develop the necessary competencies, will influence aviation normalization, focusing on airport business in the context of COVID-19, and it will develop in the future. A new airport business model in the context of COVID-19 (Figure 7) includes the achievements and opportunities brought by Industry 4.0, the requirements for HR management in a more complex context in which new knowledge and skills need to be acquired in the short term, as well as the Smart Airport Concept. Industry 4.0 made it possible to design the Smart Airport Concept. The Smart Airport Concept based on Industry 4.0, the new approach to HR, and the contactless procedure concept will be further developed to ensure the long-term sustainability of airport operations worldwide.

The limitation of the research relates to the uneven implementation of new technologies in airport operations, as they are at different stages of implementation and application of new technologies within Industry 4.0. Although part of contactless technology at the airport terminal subsystem is already in place, such as CUSS and e-gates, another part is still under development and testing. Before the COVID-19 pandemic, there was a plan for technology development and its implementation to be installed in the next 5-7 years so that airports can reach the status to become fully contactless. Nowadays, with the COVID-19 pandemic, all that process and research of different technology solutions need to speed up, and if an airport wants to continue with its business in a "new normal" situation, the deadline for the implementation of contactless technology is counted in months, not in years. Due to the above mentioned, the limitation in this research is that there is no globally fully implemented commercial contactless traffic flow at the airport subsystems, but there are still few pilot projects which are being tested. There are no exact negative aspects of using fully contactless technology in airport terminal subsystems, so after implementing the prototypes, further research should be focused on evaluating those solutions as a whole and seeing the possibility of raising their effectiveness.

The lack of new technologies at a particular airport could be solved through improvisations and adaptation, but only as part of short-term measures.

The next problem is the speed of implementation of new solutions, which can be a problem especially with the lack of financial resources for investment due to a significant drop in traffic at airports around the world.

Further research should be focused on identifying opportunities and ways for a faster and broader implementation of existing innovations within Industry 4.0, characteristic of the Smart Airport Concept, and modelling of new innovative solutions that will have their application in airport operations. 


\section{Conclusions}

The airline industry, as well as the COVID-19 pandemic, is a global phenomenon and requires a global approach. In a comprehensive approach, it is necessary to balance between the measures that will combat the pandemic and the measures that will allow the regular air traffic operations. The solutions are not unequivocal. They require: (1) innovations based on the concept of Industry 4.0, (2) competent staff for which HR management is required, and (3) management skills that ensure the synergistic effect of all three phenomena.

Achieving this balance is a time-consuming and complex task that requires financial investments. It is a process, not a state. This approach aims to determine the potential of airport operations precisely, that can be added in order to increase and maximize the efficiency of the airport operations and to choose the exact business model, which is appropriate for a given period and in line with the airports' strategy in the COVID-19 context. This approach allows the establishment of an adequate business model and long-term sustainability of airport operations even in terms of future adverse conditions. With this approach, the collapse of the airport operations can be avoided, and the possibility of defining the most appropriate business models is real.

Author Contributions: Conceptualization, M.D. and I.Š.; methodology, M.D.; validation, M.D. and I.Š.; formal analysis, M.D. and S.P.; investigation, I.Š and M.B.; resources, M.D., I.S., M.B., and S.P.; writing-original draft preparation, M.D., I.Š., M.B., and S.P.; writing-review and editing, M.D., I.Š.; visualization, M.D. and I.Š.; supervision, M.D.; project administration, M.D. and I.Š. All authors have read and agreed to the published version of the manuscript.

Funding: This research was paid by the University of Zagreb-Faculty of Transport and Traffic Science and it is part of the Scientific Project "Modeling the capacity and traffic flows of airport terminals in the conditions of the COVID-19 pandemic-no 555-5".

Acknowledgments: No additional support or contribution was made in this paper except authors.

Conflicts of Interest: The authors declare no conflict of interest.

\section{References}

1. World Health Organisation. Novel Coronavirus (2019-nCoV)—Situation Report-1; WHO: Geneva, Switzerland, 2020.

2. World Health Organization Website. Updated WHO Recommendations for International Traffic in Relation to COVID-19 Outbreak, COVID-19 Travel Advice. 29 February 2020. Available online: https://www.who.int/news-room/articles-detail/updated-who-recommendations-for-internationaltraffic-in-relation-to-covid-19-outbreak (accessed on 5 August 2020).

3. World Health Organization Website. Timeline of WHO's Response to COVID-19, Statement. 29 June 2020. Available online: https://www.who.int/news/item/29-06-2020-covidtimeline (accessed on 16 August 2020).

4. Kaminski-Morrow, D. All-Cargo Flights Stay Level as Passenger Traffic Collapses; Eurocontrol: Brussels, Belgium, 30 March 2020. Available online: https://www.flightglobal.com/air-transport/eurocontrol-all-cargo-flightsstay-level-as-passenger-traffic-collapses/137623.article (accessed on 30 March 2020).

5. Forsyth, P.; Guiomard, C.; Niemeier, H.M. The collapse in passenger demand and airport charges. J. Air Transp. Manag. 2020, 89, 101932. [CrossRef] [PubMed]

6. International Civil Aviation Organization (ICAO). State of Global Air Transport and ICAO Forecasts for Effective Plannin; Economic Development, Air Transport Bureau, ICAO: Montreal, QC, Canada, 2020.

7. International Air Transport Association (IATA). Air Passenger Demand Comes to a Standstill Amidst Lockdowns; Air Passenger Market Analysis; IATA: Montreal, QC, Canada, 2020.

8. Kotoky, A.; Stringer, D.; Saxena, R. Two-Thirds of the World's Passengers Jets Are Grounded Amid COVID-19 Pandemic. Available online: https://time.com/5823395/grounded-planes-coronavirus-storage/ (accessed on 19 June 2020).

9. International Civil Aviation Organization (ICAO). Effects of Novel Coronavirus (COVID-19) on Civil Aviation: Economic Impact Analysis; Air Transport Bureau: Montréal, QC, Canada, 3 December 2020. 
10. Kotoky, A.; Modi, M.; Turner, M. Jobs Are Being Wiped Out at Airlines, and There's Worse to Come; Bloomberg: New York, NY, USA, 2020. Available online: https://www.bloombergquint.com/business/400-000-jobs-lostat-airlines-during-coronavirus-pandemic (accessed on 21 August 2020).

11. Airports Council International (ACI). Latest Traffic Data Shows Disastrous COVID-19 Impact on Airport Industry. 7 August 2020. Available online: https://www.aci-europe.org/press-release/270-latest-traffic-data-showsdisastrous-covid-19-impact-on-airport-industry.html (accessed on 4 October 2020).

12. Airports Council International (ACI). Predicted Global Impact of COVID-19 on Airport Industry escAlates. 5 May 2020. Available online: https://aci.aero/news/2020/05/05/predicted-global-impact-of-covid-19-on-airportindustry-escalates/ (accessed on 2 December 2020).

13. Eurocontrol. Draft Traffic Scenarios for September 2020_February 2021: Impact of State Restrictions, Uncoordinated Approach and Uncertainty over COVID-19; Eurocontrol: Brussels, Belgium, 2020.

14. OAG. Coronavirus - How and When Will Aviation Recover from Covid-19? September 2020. Available online: https://www.oag.com/coronavirus-airline-schedules-data (accessed on 7 October 2020).

15. Nakamura, H.; Managi, S. Airport risk of importation and exportation of the COVID-19 pandemic. Transp. Policy 2020, 96, 40-47. [CrossRef] [PubMed]

16. Serrano, F.; Kazda, A. The future of airports post COVID-19. J. Air Transp. Manag. 2020, 89, 101900. [CrossRef] [PubMed]

17. Zahariaa, S.E.; Pietreanub, C.V. Challenges in airport digital transformation. Transp. Res. Procedia 2018, 35, 90-99. [CrossRef]

18. Nikolić, G.; Rogale, D. Industrija 4.0—Pravac Razvoja Tekstilne i Odjevne Industrije. Tekstil 2017, 66, 65-73.

19. Liao, Y.; Deschamps, F.; Freitas, E.D.; Loures, R. Past, present and future of Industry 4.0-A systematic literature review and research agenda proposal. Int. J. Prod. Res. 2017, 55, 3609-3629. [CrossRef]

20. Nikolić, G. Is industry 5.0 responding to industry 4.0 or its resume? Polytech. Des. 2018, 6, 1-8.

21. Barretoa, L.; Amarala, A.; Pereiraa, T. Industry 4.0. implications in logistics: An overview. In Proceedings of the Manufacturing Engineering Society International Conference 2017, Pontevedra, Spain, 28-30 June 2017.

22. Mrugalska, B.; Wyrwicka, M.K. Towards Lean Production in Industry 4.0. Procedia Eng. 2017, 182, 466-473. [CrossRef]

23. Qin, J.; Liu, Y.; Grosvenor, R. A Categorical Framework of Manufacturing for Industry 4.0 and Beyond. Procedia CIRP 2016, 52, 173-178. [CrossRef]

24. Schwab, K. The Fourth Industrial Revolution, What It Means and How to Respond. 2016. Available online: https://www.weforum.org/agenda/2016/01/the-fourth-industrial-revolution-what-it-means-andhow-to-respond/ (accessed on 2 September 2020).

25. Tay, S.I.; Lee, T.C.; Hamid, N.A.A.; Ahmad, A.N.A. An Overview of Industry 4.0: Definition, Components, and Government Initiatives. J. Adv. Res. Dyn. Control Syst. 2018, 10, 1379-1387.

26. Marcos, M.; Suárez, S.; Marcos, M.; Fernández-Miranda, S.S.; Marcos, M.; Peralta, M.E.; Aguayo, F. The challenge of integrating Industry in the degree of Mechanical Engineering. Procedia Manuf. 2017, 13, 1229-1236.

27. Wang, S.; Wan, J.; Li, D.; Zhang, C. Implementing Smart Factory of Industrie 4.0: An Outlook. Int. J. Distrib. Sens. Netw. 2016, 6, 1-10. [CrossRef]

28. Smit, J.; Kreutzer, S.; Moeller, C.; Carlberg, M. Industry 4.0; European Union: Brussels, Belgium, 2016 ; p. 7.

29. Crnjac, M.; Veža, I.; Banduka, N. From Concept to the Introduction of Industry 4.0. Int. J. Ind. Eng. Manag. 2017, 8, 21-30.

30. Vujić, V. Menadžment Ljudskog Kapitala; Fakultet za Turistički i Hotelski Menadžment Opatija, Sveučilište u Rijeci: Rijeka, Croatia, 2004.

31. Elwood, F.H., II; James, W.T., Jr. Trends toward a Closer Integration of Vocational Education and Human Resources Development. J. Vocat. Tech. Educ. 1996, 12, 49-57.

32. Cook, M.; Cripps, B. Psihološko Procjenjivanje na Radnome Mjestu; Školska knjiga: Zagreb, Croatia, 2009.

33. Huić, A.; Ricijaš, N.; Branica, V. Kako definirati i mjeriti kompetencije studenata-Validacija skale percipirane kompetentnosti za psihosocijalni rad. Ljetop. Soc. Rada 2010, 17, 195-221.

34. Kaslow, N.J.; Borden, K.A.; Collins, F.L., Jr.; Forrest, L.; Illfelder-Kaye, J.; Nelson, P.D.; Rallo, J.S. Competencies conference: Future directions in education and credentialing in professional psychology. J. Clin. Psychol. 2004, 60, 699-712. [CrossRef] [PubMed]

35. Ould, A.M. Business Processes; John Wiley \& Sons Ltd.: Chichester, UK, 1995. 
36. Drljača, M. Career management in the function of the management system quality. Sci. J. Saf. Eng. 2012, 2, 149-154.

37. Drljača, M.; Petar, S.; Raad, M. Development potential of passenger and baggage handling process on airports. In Proceedings of the 20th International Symposium on Quality. Quality-Yesterday, Today, Tomorrow, Pula, Croatia, 20-22 March 2019; Croatian Quality Managers Society: Zagreb, Croatia, 2020; Volume 20, pp. 257-271.

Publisher's Note: MDPI stays neutral with regard to jurisdictional claims in published maps and institutional affiliations.

(C) 2020 by the authors. Licensee MDPI, Basel, Switzerland. This article is an open access article distributed under the terms and conditions of the Creative Commons Attribution (CC BY) license (http://creativecommons.org/licenses/by/4.0/). 